\title{
後下小脳動脈瘤の臨床像と治療
}

\author{
西野 繁樹, 桑原研, 冨田 祐介 \\ 大熊佑, 田邊 智之, 村岡賢一郎 \\ 寺田 欣矢, 目黒 俊成, 廣常 信之
}

\section{Clinical Manifestation and Treatment Outcome of the Posterior Inferior Cerebellar Artery Aneurysm}

Shigeki Nishino, M.D., Ken Kuwahara, M.D., Yusuke Tomita, M.D., Yu OKuma, M.D., Tomoyuki Tanabe, M.D., Kenichiro Muraoka, M.D., Kinya TeradA, M.D., Toshinari Meguro, M.D., and Nobuyuki Hirotsune, M.D.

Department of Neurosurgery, Hiroshima City Hospital, Hiroshima, Japan

Summary: Over the past 23 years, we have experienced 42 surgical cases of the posterior inferior cerebellar artery aneurysm (PICA An); of these, 90\% (38) cases were ruptured (SAH) and $10 \%$ (four) cases were unruptured. Forty-seven surgical procedures (including 29 craniotomies and 18 endovascular procedures) were performed for all the cases. Here, we analyze the clinical findings (including grade and location) and therapeutic results.

The average patient age was 63.1 years (ranging from 23 to 82 years), and the gender ratio was 3.7 (female/male $=33 / 9)$. The locations of aneurysm were proximal (PICA origin) in $83 \%(35)$ and distal in $17 \%$ (seven) cases. Forty-three percent (18) of cases were right-sided and $57 \%$ (24) cases were left-sided. Saccular aneurysm and dissecting aneurysm were noted in $88 \%$ (36) and 12\% (five) cases, respectively. Five patients (one craniotomy case diagnosed with a dissecting aneurysm including PICA and four endovascular treatment group cases) required re-treatment. Treatment of two distal PICA aneurysms involved simultaneous trapping and occipital artery (OA)-PICA anastomosis.

For the four unruptured aneurysm cases, two underwent clipping and the others underwent endovascular surgery. The cases involving clipping reported successful closure; however, two cases in the endovascular group required re-treatment due to coil compaction.

For the $38 \mathrm{SAH}$ cases, 62\% (24) were classified as Hunt \& Kosnik (H\&K) Grade I-III (moderate-grade) and $38 \%$ (14) were H\&K Grade IV-V (poor-grade). Although $\geq 80 \%$ Grade I-III cases exhibited favorable outcomes, only $50 \%$ cases within the poor-grade group exhibited a favorable outcome. Some representative cases are described in this article.

The surgical indication for posterior circulation aneurysm is believed to be high due to the high rate of dissecting aneurysm within posterior circulation, as well as the high re-rupture and mortality/morbidity rate. However, surgical treatment of these lesions is believed to be difficult due to the deep location and critical surrounding structures, including the brain stem and lower

\author{
Key words: \\ $\cdot$ posterior inferior \\ cerebellar artery \\ aneurysm \\ - surgery \\ - coil embolization
}

Surg Cereb Stroke

(Jpn) 42: 262-269, 2014

広島市立広島市民病院 脳神経外科(受稿日 2013.10.17)(脱稿日 2014.1.20)〔連絡先： ₹730-8518 広島市中区基町 7-33 広島市立広島 市民病院 脳神経外科 西野繁樹] [Address correspondence: Shigeki Nishino, M.D., Department of Neurosurgery, Hiroshima City Hospital, 7-33 Motomachi, Naka-ku, Hiroshima 730-8518, Japan] 
cranial nerves.

Endovascular treatment is considered the first-choice treatment for posterior circulation aneurysms in many cases due to the difficulty associated with microsurgery. However, endovascular treatment of PICA An is not necessarily easy because of the relatively small size of the aneurysm, complex configuration of PICA branching, and the turnout angle between vertebral artery (VA) and PICA. The limitations of endovascular treatment should be considered in cases where it is difficult to perform coil embolization while preserving PICA blood flow.

Although the PICA aneurysm is associated with posterior circulation, its location is comparatively shallow; many PICA aneurysms located in this area are good candidates for microsurgery. Lower cranial nerve palsy, reported as a common associated morbidity in some studies, is rarely noted and may even be transient event in ordinary procedures. In many cases, the outcome primarily depends on the initial damage at the time of onset of SAH. In the present series, the outcomes of $\geq 80 \%$ patients were independent in the moderate severity group (H\&K Grade I-III) in both the craniotomy and endovascular treatment group.

We should adopt a suitable treatment strategy based on the condition of each aneurysm.

Table 1 Summary of 28 surgically treated cases

\begin{tabular}{|c|c|c|c|c|c|c|c|c|}
\hline$H \& K$ & Laterality & Location & Type & Age & Sex & 1st procedure & 2nd procedure & Outcome \\
\hline G 0 & $\mathrm{~L}$ & VA-PICA An & & 70 & $\mathrm{~F}$ & LSO/Clip & & GR \\
\hline G 0 & $\mathrm{R}$ & VA-PICA An & & 65 & $\mathrm{~F}$ & LSO/Clip & & GR \\
\hline SAH G I & $\mathrm{R}$ & distal PICA An & $\mathrm{D}$ & 82 & $\mathrm{~F}$ & MSO/Trap & & SD \\
\hline SAH G ॥ & $\mathrm{L}$ & VA-PICA An & & 69 & $M$ & LSO/Clip & & GR \\
\hline SAH G II & $\mathrm{L}$ & VA-PICA An & & 53 & $\mathrm{~F}$ & LSO/Clip & & $\mathrm{GR}$ \\
\hline SAH G II & L & VA-PICA An & & 57 & $\mathrm{~F}$ & LSO/Clip & & GR \\
\hline SAH G II & $\mathrm{R}$ & VA-PICA An & $\mathrm{D}$ & 60 & M & LSO/Trap & & $\mathrm{GR}$ \\
\hline SAH G II & L & VA-PICA An & & 44 & $\mathrm{~F}$ & LSO/Clip & & $\mathrm{GR}$ \\
\hline SAH G II & $\mathrm{R}$ & VA-PICA An & & 46 & $\mathrm{~F}$ & LSO/Clip & & GR \\
\hline SAH G ॥ & $\mathrm{R}$ & distal PICA An & & 73 & $\mathrm{~F}$ & LSO/Clip & & $\mathrm{GR}$ \\
\hline SAH G II & L & distal PICA An & & 45 & M & LSO/Clip & & $\mathrm{GR}$ \\
\hline SAH G II & $\mathrm{L}$ & VA-PICA An & $\mathrm{D}$ & 57 & $\mathrm{~F}$ & LSO/Trap/OA-PICA & & MD \\
\hline SAH G II & $\mathrm{R}$ & VA-PICA An & & 80 & $\mathrm{~F}$ & LSO/Clip & & SD \\
\hline SAH G III & L & VA-PICA An & $\mathrm{D}$ & 76 & $\mathrm{~F}$ & LSO/Clip & LSO/Clip & $\mathrm{D}$ \\
\hline SAH G III & $\mathrm{R}$ & VA-PICA An & & 79 & $\mathrm{~F}$ & LSO/Clip & & GR \\
\hline SAH G III & L & VA-PICA An & & 74 & $\mathrm{~F}$ & LSO/Clip & & GR \\
\hline SAH G III & $\mathrm{R}$ & distal PICA An & $\mathrm{F}$ & 68 & $\mathrm{~F}$ & LSO/Clip & & MD \\
\hline SAH G III & $\mathrm{L}$ & VA-PICA An & & 67 & $\mathrm{~F}$ & LSO/Clip & & $\mathrm{SD}$ \\
\hline SAH G IV & $\mathrm{R}$ & distal PICA An & & 70 & $\mathrm{~F}$ & LSO/Clip & & D \\
\hline SAH G IV & $\mathrm{R}$ & VA-PICA An & & 47 & M & IVR/TAE & LSO/Clip & GR \\
\hline SAH G IV & $\mathrm{R}$ & VA-PICA An & $\mathrm{F}$ & 49 & M & LSO/Trap & & GR \\
\hline SAH G IV & L & VA-PICA An & & 57 & $\mathrm{~F}$ & LSO/Clip & & MD \\
\hline SAH G IV & $\mathrm{R}$ & VA-PICA An & & 51 & $\mathrm{~F}$ & LSO/Clip & & MD \\
\hline SAH G IV & L & VA-PICA An & & 62 & $\mathrm{~F}$ & LSO/Clip & & MD \\
\hline SAH G IV & L & distal PICA An & $\mathrm{D}$ & 23 & $\mathrm{~F}$ & LSO/Trap/OA-PICA & & SD \\
\hline SAH G V & L & VA-PICA An & & 73 & $\mathrm{~F}$ & LSO/Clip & & $\mathrm{GR}$ \\
\hline SAH G V & $\mathrm{L}$ & VA-PICA An & & 64 & $M$ & LSO/Clip & & SD \\
\hline SAH G V & L & VA-PICA An & & 64 & $\mathrm{~F}$ & IVR/F & LSO/Clip & V \\
\hline
\end{tabular}

H\&K: Hunt \& Kosnik grade, Type (D: dissecting, F: fusiform), Procedure (LSO: lateral suboccipital craniotomy, MSO: mid-suboccipital craniotomy, Clip: neck clipping, Trap: trapping of aneurysm, OA-PICA: occipital artery-PICA anastomosis, IVR: endovascular treatment, IVR/F: failure of IVR procedure, TAE: coil embolization, Outcome (GR: good recovery, MD: moderate disable, SD: severely disable, V: vegetative, $\mathrm{D}$ : death) 


\section{緒言}

動脈瘤の根治的治療には開頭術，血管内治療があるが, より低侵襲な治療を指向する潮流と, 治療に関するアメニ ティーを求める患者希望を大きな理由として血管内治療が 選択されることが多くなってきている．特に後方循環の動 脈瘤に関しては, 開頭手術の難易度が高く, 治療合併症率 が高いことを理由として血管内治療が第一選択とされる. しかし一方で動脈㽣の形状, 血管構築によっては血管内治 療に不向きな症例が存在し，こうした症例に対してさえも 血管内治療が無理に適用されていることも少なくないよう に思われる，後下小脳動脈瘤 posterior inferior cerebellar artery aneurysm (以下 PICA An) は比較的頻度の低い部 位の動脈瘤ではあるが, 後方循環動脈瘤の中では解剖学的 に浅い部位にあり，開頭手術が良い適応と考えられる症例 も少なくなく, 治療法の選択の検討が可能かつ必要な部位 であると考えられる. 当院でのPICA Anの治療経験から， その臨床像と治療適応について検討したので報告する.

\section{対象と方法}

1989 年 (平成元年) 以降での当院での動脈瘤治療症例を 検討対象とした. 1989 年から 2012 年 4 月までの当院での 脳動脈瘤の手術件数は 1,660 件であり, 破裂瘤が 906 件 (54.6\%)，未破裂瘤が 754 件 (45.4\%)であった. 1,660 動脈 瘤の中で PICA An は 42 例 (2.5\%)であった，内訳は, 破 裂例が 38 例 (90\%), 未破裂例が 4 例 (10\%) であり, 合計 47 回の治療が実施されていた。これらの症例, 動脈瘤の
臨床像 (重症度グレード, 動脈瘤部位, 性状など) と治療法 (開頭術/血管内治療) および治療結果につき後方視的に検 討した.

\section{結果}

PICA An 42 例の性別は, 男性 9 例, 女性 34 例で, 男

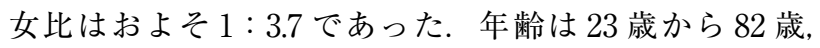
平均 63.1 歳であり, 動脈瘤の左右, 部位は右側 18 例, 左 側 24 例であり, 椎骨動脈-後下小脳動脈分岐部 (以下 VA-PICA) が 35 例, 後下小脳動脈末梢部 (以下 distal PICA)が 7 例であった. 動脈瘤の形状は囊状であったもの が 36 例，紡釺状であったものが 6 例であったが, 術前画 像評価に術中所見を加えると 5 例は解離性と判断された.

5 例で再治療が必要であったため, 開頭術が 29 回, 血 管内治療が 18 回, 合計 47 回の治療が実施された。治療法 の選択については，開頭術，血管内治療の間で明らかな優 劣がある場合を除けば，現場で治療に当たるチームの能力 に応じて治療法を選択しており，一定の基準を設けている わけではない.これらの症例を開頭治療と血管内治療に分 けてまとめたものが Table 1，2である．再治療を要した のは, 開頭治療でPICA を含む解離性動脈瘤と考えられた 1 例と, 血管内治療の 4 例であった。 また右側 VA-PICA An 破裂に対する治療後 17 年経過して新生した左 VA-PICA Anが破裂した症例が1例含まれていた.

未破裂 4 例に対して, 開頭術, 血管内治療がそれぞれ 2 例に実施され，開頭術の 2 例は成功裏に動脈瘤が閉鎖でき たが，血管内治療の 2 例中 1 例は coil compaction で再治

Table 2 Summary of 16 endovascular treated cases

\begin{tabular}{|c|c|c|c|c|c|c|c|c|}
\hline $\mathrm{H} \& \mathrm{~K}$ & Laterality & Location & Type & Age & Sex & $\begin{array}{c}1 s t \\
\text { procedure }\end{array}$ & $\begin{array}{l}\text { 2nd } \\
\text { procedure }\end{array}$ & Outcome \\
\hline G 0 & L & VA-PICA An & & 59 & $\mathrm{~F}$ & IVR/F & IVR/F & - \\
\hline G 0 & $\mathrm{R}$ & VA-PICA An & & 44 & $\mathrm{~F}$ & IVR/TAE & IVR/TAE & GR \\
\hline SAH G I & L & VA-PICA An & $\mathrm{F}$ & 39 & $M$ & IVR/PAO & & GR \\
\hline SAH G II & $\mathrm{R}$ & distal PICA An & & 77 & $\mathrm{~F}$ & IVR/PAO & & $\mathrm{GR}$ \\
\hline SAH G II & $\mathrm{R}$ & VA-PICA An & & 71 & M & IVR/TAE & & GR \\
\hline SAH G II & L & VA-PICA An & & 73 & $\mathrm{~F}$ & IVR/TAE & & $\mathrm{MD}$ \\
\hline SAH G III & $\mathrm{R}$ & VA-PICA An & & 79 & $F$ & IVR/TAE & & D \\
\hline SAH G III & $\mathrm{R}$ & VA-PICA An & & 78 & $\mathrm{~F}$ & IVR/TAE & & $\mathrm{GR}$ \\
\hline SAH G III & L & VA-PICA An & & 61 & M & IVR/TAE & & $\mathrm{GR}$ \\
\hline SAH G III & $\mathrm{R}$ & VA-PICA An & & 58 & $F$ & IVR/TAE & & MD \\
\hline SAH G IV & L & VA-PICA An & & 74 & $\mathrm{~F}$ & IVR/TAE & & D \\
\hline SAH G IV & L & VA-PICA An & & 69 & $\mathrm{~F}$ & IVR/TAE & & GR \\
\hline SAH G IV & $\mathrm{R}$ & VA-PICA An & & 47 & M & IVR/TAE & LSO/Clip & GR \\
\hline SAH G IV & L & VA-PICA An & & 62 & $\mathrm{~F}$ & IVR/TAE & & $\mathrm{MD}$ \\
\hline SAH G IV & $\mathrm{R}$ & VA-PICA An & & 71 & $\mathrm{~F}$ & IVR/TAE & & V \\
\hline SAH G V & L & VA-PICA An & & 64 & $\mathrm{~F}$ & IVR/F & LSO/Clip & V \\
\hline
\end{tabular}


Table 3 Treatment outcome

\begin{tabular}{|c|c|c|c|c|c|c|c|}
\hline \multirow{2}{*}{ H\&K Grade } & \multirow{2}{*}{ Total No. } & \multicolumn{3}{|c|}{ Clip (28) } & \multicolumn{3}{|c|}{ IVR (13) } \\
\hline & & GR/MD & SDN & $D$ & GR/MD & $\mathrm{SD} / \mathrm{N}$ & $\mathrm{D}$ \\
\hline 0 & 3 & 2 & 0 & 0 & 1 & 0 & 0 \\
\hline$|-|||$ & 24 & 13 & 2 & 1 & 7 & 0 & 1 \\
\hline IV-V & 14 & 5 & 3 & 2 & 2 & 1 & 1 \\
\hline
\end{tabular}

GR: good recovery, MD: moderate disable, SD: severely disable, V: vegetative, D: death

療が必要であった．破裂例（くも膜下出血例） 37 例の重症 度は，軽症である Hunt \& Kosnik grade（以下 H\&K Grade) G I-III が 24 例 (62\%), G IV-V の重症例が 14 例 (38\%)であり, 軽症例では $80 \%$ 以上が favorable outcome (GR/MD)であったのに対して, 重症例ではその割合は 50\%に止まっていた（Table 3).

治療内容を治療法ごとに検討した，血管内治療を行った 16 例では, 未破裂 1 例は治療が断念され経過観察のみと なり，未破裂のもう 1 例は約 8 カ月で coil compactionの ため再治療 (血管内)を要した(症例 1 )。 また破裂例で, 血 管内治療を途中断念し開頭術に切り替えた例が 1 例, コイ ル塞栓術後約 1 力月で再破裂し開頭術を行った例が 1 例 あった(症例 2)。一方, 開頭術を行った 29 例では, 最終 的に解離性と判断された 1 例のみ初回クリッピングの 1 週 間後に再破裂し再手術が行われた(症例 3). distal PICA $\mathrm{An} へ の$ 開頭症例の 2 例で OA-PICA anastomosis を併用 しての PICA 本幹を含めた trapping が行われた (症例 4).

破裂右 VA-PICA Anの治療後 17 年を経過して左 VA-PICA が破裂した例が 1 例, また長期間経過後(14 年 目, 15 年目)同一部位での再発を認めた例が 2 例であった.

以下，代表症例を提示する。

\section{症例 提示}

〈症例 1〉40 歳代女性の未破裂 R. VA-PICA An 症例で, 頝部痛に対する近医での検查で椎骨動脈の解離と診断さ れ，フォローアップ MRで解離部に囊状動脈瘤が発生し ていることが判明し, 当科に紹介された。瘤最大径は 4.5 mm (Fig. 1A) で, 血管内治療を行った. Presidio, US, EDESなどでコイル塞栓を実施し, 体積塞栓率は 46\%で終了したが, わずかに neck remnantを残した(Fig. 1B). 半年後のフォローアップ画像で coil compaction を 認め(Fig. 1C), 脳血管撮影で neck 付近の再開通が確認さ れたため初回治療の 8 カ月後に再度コイル塞栓を追加した

(Fig. 1D).

〈症例 2〉40 歳代男性の R. VA-PICA An 破裂例で, 3 年前に破裂右中大脳動脈瘤に対する手術を受けていた。 入 院時, JCS: 100, GCS: E1V1M3, 四肢麻痺, 曈孔は両側

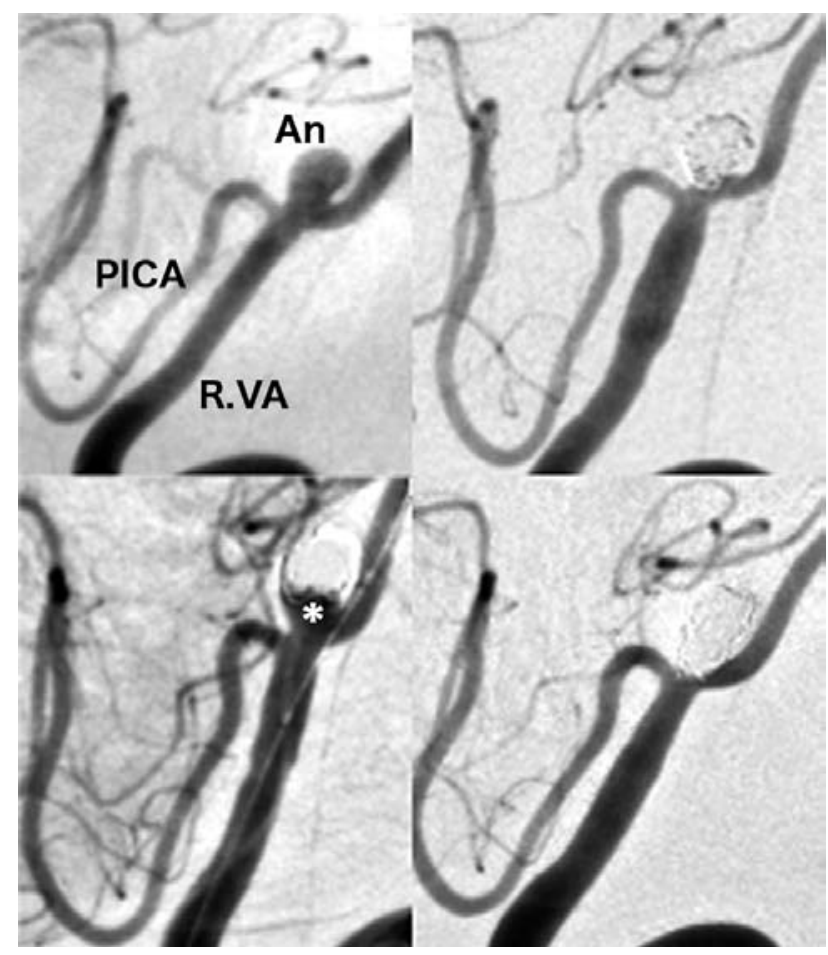

Fig. 1 Case 1.

A) Preoperative R. VAG: The aneurysm (An) was arose from just proximal PICA origin.

A $\mid$ B $\quad$ B) Post- 1st TAE R. VAG: The aneurysm was filled $\overline{\text { C }} \mathbf{D}$ completely with coil.

C) Six months follow up R. VAG: The neck remnant $\left({ }^{*}\right)$ was appeared due to coil compaction.

D) Post- 2nd TAE R. VAG: The residual part of aneurysm also re-filled with coil.

縮曈し対光反射は鈍麻であった. CT では両側小脳橋角部, 橋前槽を中心に厚いくも膜下血腫を認め(Fig. 2A), H\&K G IV の SAH と診断した。血管撮影で右 VA-PICA Anの 破裂と確認され(Fig. 2B), 同日, 緊急でコイル塞栓術を 実施したが，術中コイルの一部が瘤外に逸脱したため出血 点を中心にコイル充塡した (Fig. 2C). 術後, 一時気管切 開管理をしたが抜管もできていた，1 カ月でのフォロー アップ CT でくも膜下出血の再発を認め, 血管撮影で coil compaction とともに動脈瘤再発が確認されたため(Fig. 


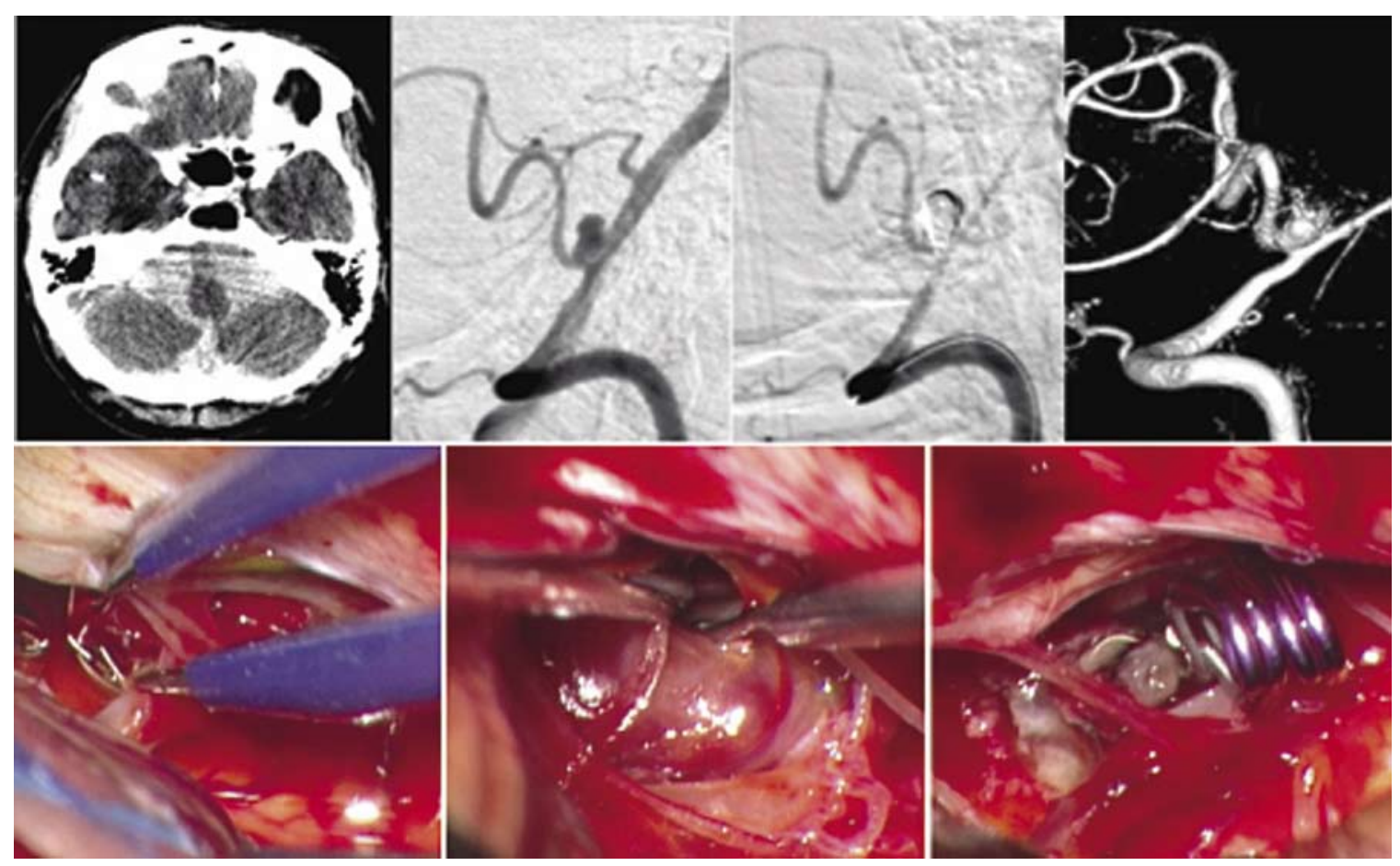

Fig. 2 Case 2.

A) The CT scan obtained on admission revealed thick SAH within the perimedullary cistern.

B) Preoperative R. VAG: The aneurysm was arose from just proximal PICA origin.

C) Post- 1st TAE R. VAG: The aneurysm was filled completely with coil.

A $\mid$ B $\mid$ C $\mid$ D

D) R. VAG obtained 2nd SAH attack one month after TAE: The neck remnant was appeared due to coil compaction.

E) Intraoperative photo\#1 showed extra-aneurysmal part of the coil behind lower cranial nerves.

F) Intraoperative photo\#2 showed the aneurysmal neck and the dome.

G) Intraoperative photo\#3 showed complete neck clipping of the aneurysm with two mini-titanium clips.

2D), day 35 に, 右後頭下開頭で neck clipping を行った

(Fig. 2E, F, G). 術後神経学的には, 軽度下位脳神経麻痺 (嚥下障害, 構音障害)のみで, 独歩自宅退院した。

〈症例 3〉70 歳代女性の L. VA-PICA An からのくも膜 下出血症例である，仕事中に突然の頭痛で発症し，近医受 診しSAH と診断され当科に紹介された．初診時 JCS： 20 で左外転神経麻疩, 右不全麻痺を認め, CT では左小脳橋 角部に厚いくも膜下血腫を認め(Fig. 3A), H\&K G III の SAH と診断した. 血管撮影で左 VA-PICA An と診断し たが, PICA 分岐部のVA 壁にも紡錘状の膨らみを認めて いた(Fig. 3B)。破裂部位はVA-PICA の囊状動脈瘤と判 断し, 左後頭下開頭で neck clipping を行った. 術中所見 でも動脈瘤は二段構造で上部の瘤(bleb?) を破裂部位と判 断し下段から分岐する PICA を残すように, Bayonet clip (FT728D)で neck clipping を行った. 内視鏡で確認し膨 らんだVAの壁の薄い部分も fenestrated clip (FT639T) をかけることで処理し, マイクロドプラで PICA 血流も確
認した(Fig. 3C，D，E)。術後順調に経過していたが， day 7 に再破裂し, 再開頭すると椎骨動脈を含む血管解離を認 めたため, 止血のために PICA を sacrifice せざるを得ず (Fig. 3F), 術後小脳梗塞を合併した. day 18 に massive GI bleeding (duodenal ulcer)にてショックとなり, day 21 に死亡した.

〈症例 4〉 20 歳代女性の破裂 R. distal PICA An の症例 である，小児白血病で骨髄移植，大腿骨頭壊死による手術 の既往があった．PC 作業中に突然の項部痛，右足のしび れを自覚し，その後心肺停止し，心肺蘇生を受けながら当 院に搬入された。入院時, JCS: 100 で, 四肢の自動運動 をわずかに認めるのみであった，CTでは橋前槽を中心に 厚いくも膜下血腫を認め(Fig. 4A), H\&K G IV の SAH と診断した．血管撮影で右 AICA-PICA 末梢部の紡錘状動 脈瘤(Fig. 4B)の破裂と判断し, 右後頭下開頭で OA-PICA 吻合を行ったうえで動脈瘤の trappingを行った(Fig. 4C, D, E)。意識は回復したが, 下位脳神経麻痺(嚥下障害, 構音 


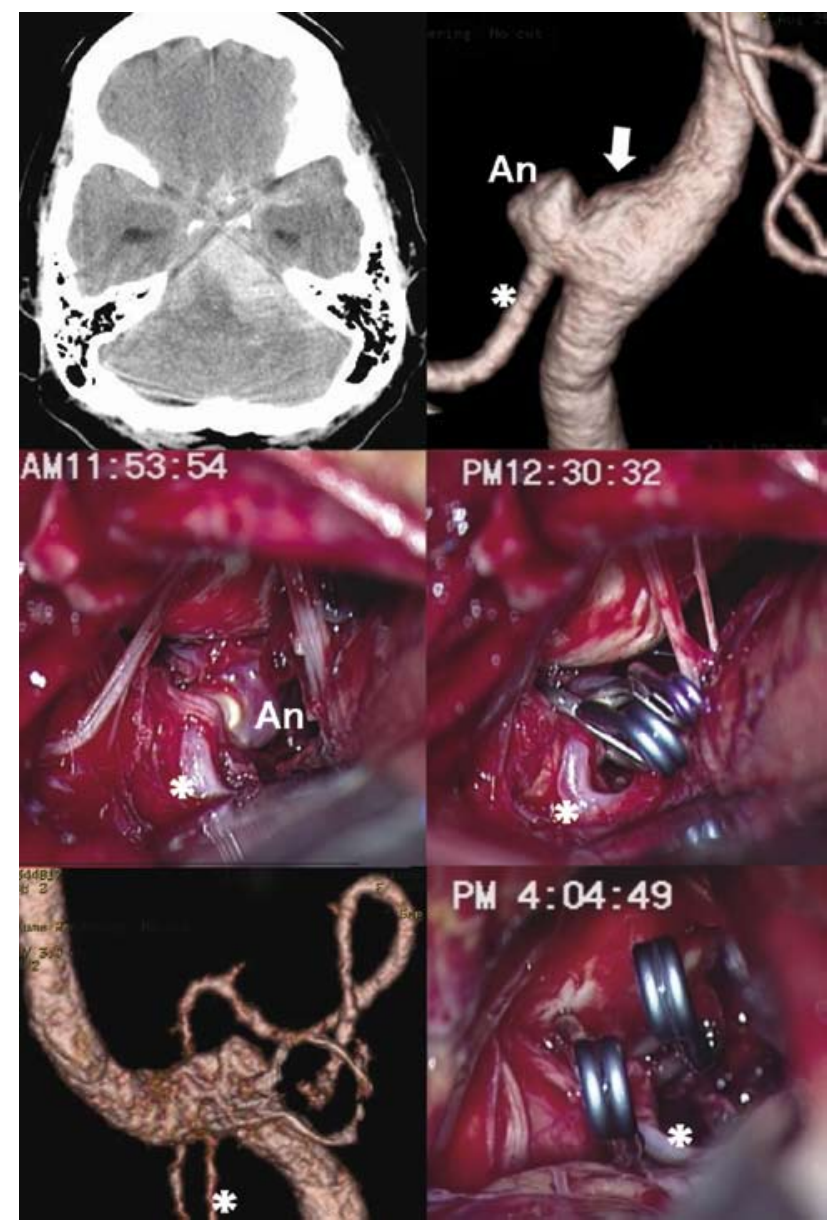

\section{\begin{tabular}{l|l}
$\mathbf{A}$ & $\mathbf{B}$ \\
\hline $\mathbf{C}$ & $\mathbf{D}$ \\
\hline $\mathbf{E}$ & $\mathbf{F}$
\end{tabular}}

Fig. 3 Case 3.

A) The CT scan obtained on admission revealed thick $\mathrm{SAH}$ within the left $\mathrm{CP}$ angle cistern.

B) Preoperative L. VAG: The aneurysm (An) was arose from just proximal PICA (*) origin and slight buldging of the L. dorsal VA wall (arrow).

C) Intra- 1st operative photo\#1 showed thin aneurysmal wall mounding VA-PICA junction wall between the lower cranial nerves.

D) Intra- 1st operative photo\#2 showed mini-bayonet clip obliteration of thin aneurysmal wall and adjunctive clipping thin wall of L. VA.

E) Post- 1st operative L. VAG: The aneurysm and buldging VA wall were obliterated with clips, and PICA $\left({ }^{*}\right)$ was patent.

F) Intra- 2nd operative photo showed clip obliteration of thin aneurysm wall with PICA $\left({ }^{*}\right)$.

Fig. 4 Case 4.

A) The CT scan obtained on admission revealed thick SAH within the perimedullary cistern.

B) Preoperative L. VAG: The fusiform aneurysm (arrow) was arose at the anastomotic arcade of AICA and PICA (*).

C) Intraoperative photo\#1 showed the aneurysm (arrow) of AICA-PICA $\left({ }^{*}\right)$ arcade.

D) Intraoperative photo\#2 showed trapping of the aneurysm and OA-PICA anastomosis.

E) Intraoperative ICG fluoroangiography showed complete obliteration of the aneurysm and PICA opacified through OA-PICA anastomosis.

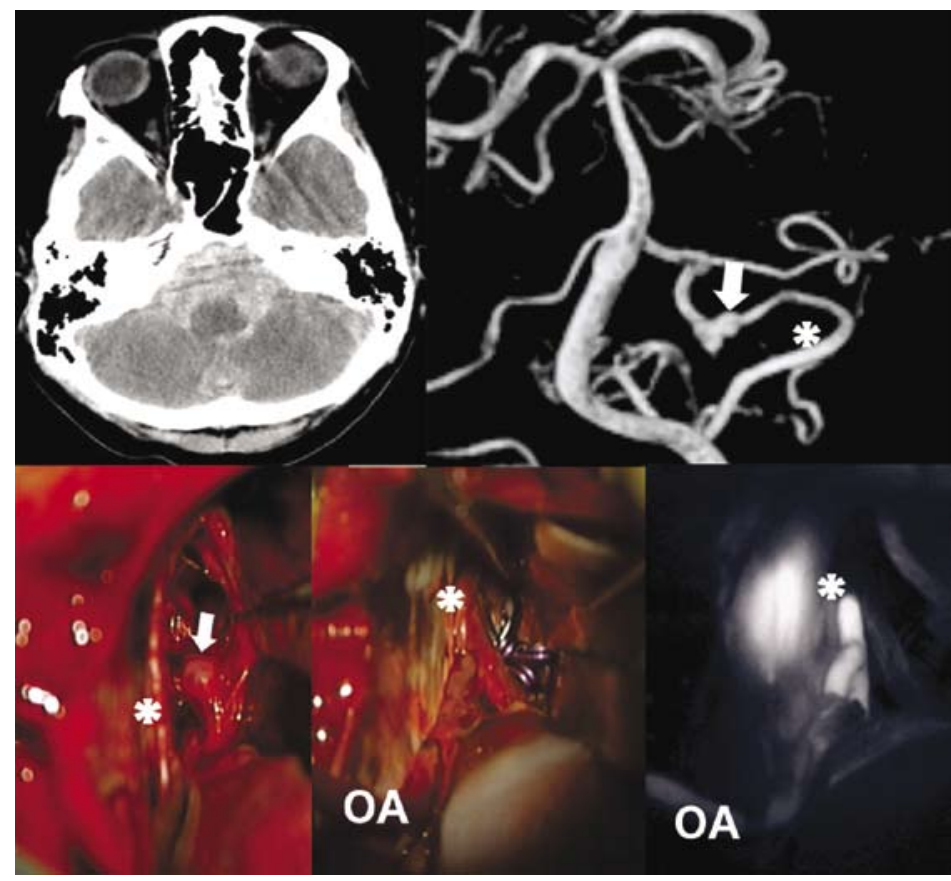

Surgery for Cerebral Stroke 42: 2014 
障害) と四肢不全麻痺を後遺し回復期リハビリテーション 病院に転院した.

\section{考察}

後方循環の動脈瘤は, 解離性動脈瘤の割合も高く, 特に 破裂例での再破裂率, mortality/morbidity rate が高く治 療適応はより高いと考えられている。一方で, 深部で, 脳 幹や下位脳神経などの重要構造物が近く, 手術は容易でな いとされる.

椎骨動脈瘤は 1829 年にCruveilhier が最初に報告し2), Krayenbuhl や Dandy らが 1940 年代にその治療に関して 報告している ${ }^{6)}$. しかし椎骨動脈瘤に対する初期の報告は, morbidity, mortality ともに非常に高く, その治療は“挑 戦的”と記載されていた．顕微鏡手術の導入により Drake が椎骨脳底動脈瘤に対する多数の治療成功例を報告し ${ }^{3)}$, さらに頭蓋底手術手技の導入, 脳保護薬剂の開発などが加 わることで，その治療成績は向上してきている ${ }^{12)}$.

後下小脳動脈 (PICA) に関連する動脈瘤については, Pia の報告によれば PICA An を含む後方循環の動脈瘤は頭蓋 内動脈瘤の $8 \%$ で, PICA An はその $25 \%$ を占めていた ${ }^{8)}$. 日本からの 1,230 例の剖検例の検討では頭蓋内動脈瘤の 9.6\%が PICA Anであったと報告されている. Yamaura らは後方循環動脈瘤の $28 \%$ が椎骨動脈解離性動脈瘤で あったとも報告している ${ }^{11)}$.

開頭手術の難易度の高さのために, 後方循環の動脈瘤で は血管内治療が第一選択とされることが多いことは先に述 べた．しかし PICA An は比較的小さなものが多く，また PICA の分岐角度が急峻であることなど, 必ずしも血管内 治療が容易なものばかりではない ${ }^{177}$. 実際に今回のシリー ズでも，血管内治療を実施した 17 例中 3 例 (17\%)に再治 療を要しており, コイル塞栓術で確実な塞栓を得ることが 困難な例も含まれていたと考えられる．またアクセスに問 題があり治療を断念した症例も含まれていた．動脈瘤の部 位や形状にもよるが，比較的細い分枝である PICA の血流 を温存しつつコイル塞栓術を実施することが困難な場合が あることにも留意が必要である。こうした点を踏まえて当 科では, 動脈瘤の大きさ, 親血管の分岐角度など, 血管内 治療での困難が予想される症例では, さまざまな工夫を行 うとしても，その治療法の選択はより慎重に行う方針とし ている.

一方, PICA An は後方循環ではあるが，解剖学的には 比較的“浅い”位置にあり, 開頭術で到達可能な部位であ り, 下位脳神経の処理などの手技上の注意は必要であるが 開頭術の良い適応となる例も多い，ただしその部位が正中 に近くなるほど治療は困難となり，手術合併症の危険性も 高くなる ${ }^{910)}$ ．われわれの症例では多くが通常の外側の部
位であり，28 例に開頭術が行われ，解離性であった 1 例 を除いて問題なくクリッピングなどの外科処置が実施でき た，下位脳神経麻疩は，文献上，頻度が高いとの報告が多 い.しかし，手術手技自体に起因するものは少なく，また 一過性であり改善の可能性も高く ${ }^{4)}$, 障害の強かったもの はくも膜下出血発症時の initial damage に起因することが 多く,われわれのシリーズでは開頭術, 血管内治療ともに, 軽症くも膜下出血例 (H\&K Grade I-III) では $80 \%$ 以上が GR/MD と良好な治療結果であった．開頭術で早期に再出 血した例は，親血管である椎骨動脈も含んだ解離性であっ たと考えられ，動脈瘤およびその親血管の壁の性状を正確 に判断したうえで治療適応，親血管の trapping を含めた 手術方法の選択に配慮が必要であったと考えられた。

また今回のシリーズの中には, 初回のくも膜下出血を発 症/治療してから 14 年目, 17 年目に再発/再出血していた 症例も含まれており, 根治治療後の長期生存例に対する, さらに長期間のフォローアップの必要性に関しても検討す る必要があると考えられた。

\section{結 論}

当院におけるPICA Anの臨床像につき検討した. PICA An は後方循環ではあるが, 開頭術でも比較的到達 の容易な部位でもあり開頭術の適応となる例も多い。一 方, 再治療を要した例には十分な塞栓率が得られなかった コイル塞栓例も含まれており，比較的細い分枝である PICA を温存した血管内治療が困難な場合があることにも 留意が必要である。

本論文の要旨は, 第 41 回日本脳卒中の外科学会 $(2012$ 年 4 月 26 日, 福岡)において発表した.

また著者全員は日本脳神経外科学会への COI 自己申告 を完了しており，本論文の発表に関して開示すべきCOI はありません。

\section{文献}

1) Cho YD, Kang HS, Lee WJ, et al: Stent-assisted coil embolization of wide-necked posterior inferior cerebellar artery aneurysms. Neuroradiology 55: 877-882, 2013

2) Cruveilhier J: Anatomie Pathologique de Corps Humain. Vol 2, Paris, JB Bailliere, pp1829-1835

3) Drake CG: The treatment of aneurysms of the posterior circulation. Clin Neurosurg 26: 96-144, 1979

4) Horowitz M, Kopitnik T, Landreneau F, et al: Posterior cerebellar artery aneurysms: Surgical results for 38 patients. Neurosurgery 43: 1026-1031, 1998

5) Hudgins RJ, Daz AL, Quisling RG, et al: Aneurysms of the posterior inferior cerebellar artery. A clinical and anatomical analysis. $J$ Neurosurg 58: 381-387, 1983

6) Krayenbuhl H, Yasargil MG: Variationen der A. Verte- 
bralis, Basilalis und ihrere Äste, in Die Vaskularen Erkrankungen in Gebiet der Arteria Vertebralis und Arteria Basilalis. Stuttgart, Thieme Verlag, 1957

7) Peluso JP, van Rooji WJ, Sulzewski M, et al: Posterior inferior cerebellar artery aneurysms: incidence, clinical presentation, and outcome of endovascular treatment. AJNR Am J Neuroradiol 85: 86-90, 2008

8) Pia HW: Classification and treatment of aneurysms of the vertebro-basilar system. Neurol Med Chir (Tokyo) 19: $575-594,1979$

9) Salcman M, Rigmonti D, Numaguchi Y, et al: Aneurysms of the posterior inferior cerebellar artery-vertebral artery complex: variations on a theme. Neurosur- gery 27: 12-20, 1990

10) Yamaura $A$, Ise $H$, Makino $H$ : Radiometric study on posterior inferior cerebellar aneurysms with special reference to accessibility by the lateral suboccipital approach. Neurol Med Chir (Tokyo) 21: 721-723, 1981

11) Yamaura $\mathrm{A}$, Isobe $\mathrm{K}$, Karasudani $\mathrm{H}$, et al: Dissecting aneurysms of the posterior inferior cerebellar artery. Neurosurgery 28: 894-898, 1991

12) Yasargil MG: Microneurosurgery. II Clinical considerations, surgery of the intracranial aneurysms and results. Stuttgart; New York: Thieme; New York, 1984, pp281-295 